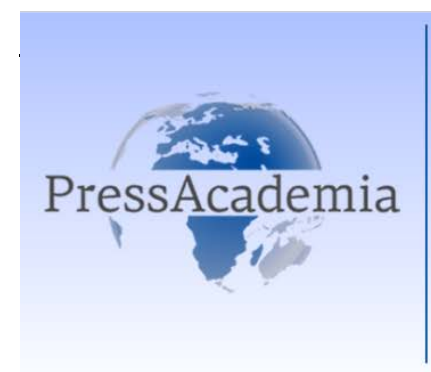

Press Academia Procedia

Global Business Research Congress (GBRC), May 26-27, 2016, Istanbul, Turkey.

\title{
INVESTIGATION OF TOURISM EMPLOYEES' INTERCULTURAL SENSITIVITY LEVELS IN TERMS OF VARIOUS DEMOGRAPHIC VARIABLES
}

DOI: 10.17261/Pressacademia.2016118630

\author{
Muammer Bezirgan ${ }^{1}$, Bayram Alamur ${ }^{2}$ \\ ${ }^{1}$ Balıkesir Üniversitesi, muammerbezirgan@balikesir.edu.tr \\ ${ }^{2}$ Balıkesir Üniversitesi, alamur bayram@hotmail.com
}

\begin{abstract}
The aim of this study was to determine the level of intercultural sensitivity among the staff working in the tourism business and the employees of intercultural sensitivity levels according to age is to determine whether the significant difference. The study which of tourism businesses operating in the Gulf of Edremit (hospitality business and travel agents), the data collected through the survey to work with 517 determined by the easy sampling method. In analysis of the data, factor analysis, independent samples "t test" and is used one-way analysis of variance. As a result, significant differences in demographic characteristics of intercultural sensitivity level employees have been identified.
\end{abstract}

Keywords: Intercultural sensitivity, tourism workers, demographic variables.

JEL Codes: M11, L83.

\section{TURIZM ÇALIŞANLARININ KÜLTÜRLERARASI DUYARLILIK DÜZEYLERINNIN ÇEŞITLi DEMOGRAFIK DEĞiŞKENLERE GÖRE INCELENMESI}

\section{ÖZET}

Bu araştırmanın amacı turizm işletmelerinde çalışan personelin kültürlerarası duyarlıık düzeylerinin belirlenmesi ve çalışanların demografik özelliklerine göre kültürlerarası duyarlıık düzeyleri arasında anlamlı fark olup olmadığının tespitidir. Çalışma Edremit Körfezinde faaliyet gösteren Turizm işletmelerinde (konaklama işletmeleri ve seyahat acentaları)kolayda örnekleme yöntemiyle belirlenen 517 çalışan ile anket aracılığıyla veri toplanarak gerçekleştirilmiştir. Araştırma verilerinin analizinde açıklayııı faktör analizi ile farklılık analizlerinde bağımsız örneklem "t testi" ve tek yönlü varyans analizi kullanılmışır. Araştırma sonucunda çalışanların demografik özelliklerine göre kültürlerarası duyarlıık düzeylerinde anlamlı farkıııklar tespit edilmiştir.

Anahtar Kelimeler: Kültürlerarası duyarlılık, turizm çalışanları, demografik değişkenler. JEL Kodları: M11, L83. 


\section{GíRiş}

Konaklama işletmelerinin sayılarının giderek artması ve faaliyetlerini uluslar arası boyutta taşımaları ile birlikte oluşan yoğun rekabet, işletmelerde sunulan kaliteli hizmeti rekabet gücü elde etmede ön plana çıkarmaktadır. İşletmelerin konaklama işletmelerinden satın aldıkları hizmetlerden tatmin olmadıklarında, turistlerin seyahat deneyimleri olumsuz sonuçlanabilecektir. Tüketicilerin herhangi bir ürüne karşı satın alma davranışlarını etkileyen en önemli faktörlerden birinin kültür olması nedeniyle, bireyci ve toplumcu kültürlerden gelen turistlerin istek ve gereksinimlerinin neler olduğunu saptamak, onların istek ve gereksinimlerine uygun konaklama işletmeleri geliştirilebilmesi açısından büyük bir önem taşımaktadır. (Belber 2009). Kültürlerarası etkileşimin yoğun olduğu, farklı kültürler özelliklere sahip bir müşteri profilinin bulunduğu turizm işletmelerinde, en önemli konulardan bir tanesi kültürel farklılıklar ve bu farklılıkların turizm işletmeleri açısından getireceği avantaj ve dezavantajlardır. Kültürel farklılıklar işletmelere çeşitli stratejik faydalar sağlayabileceği gibi, birçok problemin de ana kaynağı olabilecektir. Kültürel farklılıkların yoğun olarak yaşandığı turizm işletmelerinde kültürel farklılıklar en iyi şekilde yönetilmeli ve işletmelerin faydalarına kullanılmalıdır. Kültürel farklılıkların yönetilmesinde çeşitli örgütsel ve bireysel stratejiler vardır. Turistlerin seyahatlerinden tatmin olması sonucunda da hem konaklama işletmesinin kârı artacaktır hem de bu durum ülke ekonomisine olumlu katkı sağlayacaktır. Kültürlerarası iletişim olgusunun, farklı kültür ve aidiyet bağlarının iletişim ve etkileşim örüntülerini ele almasının ötesinde kültürlerarası diyaloga yönelik bir çağrıyı barındırdığı da söylenebilir. Bu noktada Selçuk'un (2005: 2) da belirttiği gibi; iletişime katılan kişiler, farklı bir kültüre mensup bireylerin iletişim davranışlarını bilmediği sürece ifadeleri, tutum ve davranışları kendi kültürel normlarına ve standartlarına göre anlamlandırmayı tercih edecektir. Bu durum da kültürlerarası etkileşim sürecinde iletişim çatışmalarının yaşanmasını her an için beklenir hale getirir. İletişim becerileri, konuşma, yazma, okuma, dinleme ve düşünme ile ilgilidir. İletişim becerilerinin doğuştan ve sezgi yoluyla gerçekleştiğini düşünenler olsa da pek çok çalışma iletişim tekniklerinin çoğu öğesinin öğrenilebilir ve öğretilebilir özellikler gösterdiğini göstermektedir (Egan, 1994). Kültürler arasındaki iletişim sürecinde sağlam eğitim ve kültür altyapısına sahip olmayan bireylerin davranışlarında bazı sapmalar ortaya çıkabilmektedir (Çakır, 2010:80). Ortaya çıkan bu sapmalar özellikle emek-yoğun bir yapıya sahip turizm işletmelerinde müşteri memnuniyetini olumsuz etkileyebilir. Misafir ile doğru bir iletişim sürecinin kurulmasında çalışanların kültürler arası duyarlıık düzeyleri önem arz etmektedir. Buradan hareketle bu çalışmada Turizm işletmelerinde çalışan personelin kültürel duyarlılık düzeyleri tespit edilerek, çalışanların demografik özelliklerine göre kültürel duyarlılık düzeyleri arasında fark olup olmadığı tespit edilmeye çalışılacaktır. Bu amaç kapsamında aşağıdaki araştırma soruları geliştirilmiştir.

$H_{1}$ : Turizm çalışanlarının cinsiyetlerine göre kültürel duyarlııkları arasında istatistiksel olarak anlamlı farklııklar vardır.

$\mathrm{H}_{2}$ : Turizm çalışanlarının medeni durumlarına göre kültürel duyarlılıkları arasında istatistiksel olarak anlamlı farklılıklar vardır.

$\mathrm{H}_{3}$ : Turizm çalışanlarının yabancı dil bilgilerine göre kültürel duyarlılıkları arasında istatistiksel olarak anlamlı farklılıklar vardır.

$\mathrm{H}_{4}$ : Turizm çalışanlarının yaş aralıklarına göre kültürel duyarlılıkları arasında istatistiksel olarak anlamlı farklılıklar vardır.

$H_{6}$ : Turizm çalışanlarının eğitim düzeylerine göre kültürel duyarlılıkları arasında istatistiksel olarak anlamlı farklılıklar vardır.

$H_{5}$ : Turizm çalışanlarının iş pozisyonlarına göre kültürel duyarlılıkları arasında istatistiksel olarak anlamlı farklılıklar vardır.

$H_{7}$ : Turizm çalışanlarının çalışma sürelerine göre kültürel duyarlılıkları arasında istatistiksel olarak anlamlı farklılıklar vardır.

Araştırma bulguları ışı̆̆ında turizm sektöründe dolaylı ya da dolaysız yer alan işletmelere yönelik bazı önerilerde bulunulacaktır. 


\section{KÜLTÜRLERARASI DUYARLILIK KAVRAMI}

Kültürlerarası duyarııık, kültürel farkıııkların tanımlanmasında ve değerlendirilmesinde uygun ve etkili davranış biçimini teşvik eden kültürlerarası iletişim açısından pozitif duygu geliştirebilme yeteneği olarak tanımlanmaktadır. Böyle bir tanımlama, kültürlerarası duyarlılığın dinamik yapısına işaret etmektedir. Bu durum ise kültürlerarası duyarlıı̆̆a sahip bireylerin; farklılıkları anlamaya, onaylamaya ve kabul etmeye yönelik motive edici bir istek ve eğilime sahip olmaları gerektiğine işaret etmektedir. Kültürlerarası duyarlılık; kültürler arası etkileşim durumunun bilişsel, duygusal ve davranışsal yönleriyle ilgilenmekle birlikte, temel olarak duygusal alanla ilgilidir (Chen 1997:15). Farklı kültürlerden gelen insanlar arasındaki mesafelerin azalması, kültürlerin birbirlerini tanımalarına olanak sağlamakla birlikte bu kültürlerin birbirleriyle çatışma içine girmelerine de neden olmaktadır. Önyargılar, algısal farklılıklar, yanlış anlamalar, olumsuz stereotipler, kültürel şoklar ve entomerkezci yaklaşımlar farklı kültürlerden gelen insanların bir arada yaşamasını ve iletişim kurmasını engelleyen en önemli unsurlardır. Bu engellerin aşılması ve kültürlerarası iletişimin gerek bireysel gerekse kurumsal düzeyde geliştirilmesi gerekmektedir (Aksoy,2012: 303). Kültürlerarası duyarlılığın temel göstergesi olarak farklı kültürlere, alt kültürlere ve aidiyet bağlarına yönelik olumlu duygularla yaklaşılması gerekliliğidir. Olumlu duygulardan kasıt ise farklııkların önyargısız, stereotipler kullanılmaksızın, etnomerkezcilikten uzak ve yargılanmaksızın değerlendirilmesidir. Bu da anlama, tanıma, onaylama, saygı gösterme, görecelik gibi özelliklerle karakterize olan bir duygu dünyası gerektirmektedir (Bekiroğlu ve Balcı, 2014: 434).

Kültürlerarası duyarlılık, kültürel farklılıkları anlamaya ve olumlamaya yönelik pozitif duyguların geliştirilebilmesi olarak tanımlanmakta ve bu doğrultuda kültürlerarası yeterliğin desteklenmesi için bireylerin sahip olmaları gereken birtakım özelliklere dikkat çekmektedir. Bu özellikler; özsaygı, özdenetim, açık fikirlilik, empati, etkileşimli ilişki ve önyargılı ya da peşin hükümlü olmama şeklinde sıralanmaktadır (Chen, 1997:23). Hammer'a göre (2003: 422), kültürler arası duyarlılık, kültürel farklılıklarla ilgili olarak deneyimleme ve farkında olma becerisidir. Kültürel duyarlılığa sahip çalışanların yabancı müşterilere daha iyi hizmet sundukları ve sonuçların üstlerini daha fazla memnun ettiğini söylemek mümkündür. Konaklama sektöründe özellikle zincir otellerin farklı ülkelerde hizmet vermesi ile sınır ötesi ortaklıklar meydana gelmekte ve giderek farklı ülke vatandaşlarının aynı çatı altında birbirleri ile uyum içerisinde yaşamak zorunda oldukları çok kültülü ortamlar oluşmaktadır. Kültürlerarası iletişim, farklı kültürel ve alt kültürel art alanlara, bilgi ve deneyimlere sahip bireyler arasında gerçekleşen iletişim ve etkileşimi ifade etmektedir. Bir disiplin olarak kültürlerarası iletişimin kavramsal çerçevesi ve ilgi alanı, zaman içerisinde özellikle etnik ve ırksal açıdan farklılaşan iç alt kültürel grupları da kapsayacak şekilde genişlemiştir (Kim 2005: 554-555).

\section{GEREÇ VE YÖNTEM}

\subsection{Araştırmanın Amacı}

Bu araştırmanın amacı; Turizm işletmelerinde çalışan personelin kültürel duyarlılık düzeyleri tespit edilmesi ve çalışanların demografik özelliklerine göre kültürel duyarlıık düzeyleri arasında anlamlı fark olup olmadığının tespitidir.

\subsection{Araştırmanın Evreni ve Örneklemi}

Araştırmanın evrenini Edremit Körfezinde yer alan Turizm işletme Belgeli Otel İşletmeleri ve A grubu seyahat acenteleri oluşturmaktadır. Edremit körfezinde toplam 49 adet turizm işletme belgeli otel işletmesi (www.ayvalık.gov.tr; www.balikesir-edremit.gov.tr; www.burhaniye.bel.tr) ve 43 adet A,B ve C grubu seyahat acentası bulunmaktadır (www.tursab.gov.tr). Bu işletmelerde çalışan 588 çalışana kolayda örnekleme yöntemi ile ulaşıımış ve anketler yüz yüze görüşülerek gerçekleştirilmiştir. 3.3.Verilerin Değerlendirilmesi ve Analizi Araştırmada verilerin değerlendirilmesinde SPSS 20.0 (Statistical Program for Social Science) paket programı \%95 güvenilirlik seviyesinde kullanılmışır. Araştırmada kullanılan ölçeğin güvenirliğini test etmek için güvenilirlik analizi, bağımsız grupların değerlendirilmesinde ise t-testi ve tek yönlü ANOVA testi kullanılmıştır. Anova analizleri sonucu anlamlı fark çıkan faktörlerin ileri analizleri için ise Tukey's testi kullanılmıştır. Ayrıca anketin her bir maddesine ilişkin frekans değerleri de hesaplanmıştır. Olguların sosyodemografik özelliklerinin dağılımında yüzdelik, kültürel duyarlılık çalışmalarını değerlendirmesinde ise 
ortalama puanlar kullanılmıştır. Güvenilirlik acısından cronbach'ın alfa testi uygulanmış ve katsayı 0,84 olarak bulunmuştur. $>0,75$ olduğundan dolayı bilimsel olarak kabul görür.

\subsection{Veri Toplama Araçları}

Veri toplama aracı olarak araştırmacı tarafından oluşturulan Anket Formu kullanılmıştır. Kültürler arası Duyarlılık Ölçeği (KDÖ) Chen ve Staros'ta tarafından geliştirilen ve kültürlerarası duyarlılığı ölçmek için gerekli beş duygusal boyutu içeren bir ölçektir ve Likert tipi 24 sorudan oluşmaktadır. Ölçeğin iletişimde sorumluluk boyutu 1, 11, 13, 21, 22, 23 ve 24. Maddelerden, kültürel farklılıklara saygı boyutu 2, 7, 8,16, 18 ve 20. Maddelerden iletişimde kendine güvenme boyutu 3, 4, 5, 6 ve 10. Maddelerden iletişimden hoşlanma boyutu 9, 12 ve 15. Maddelerden iletişimde dikkatli olma boyutu 14, 17 ve 19. Maddelerden oluşmaktadır. Ölçeğin 2, 4, 7, 9, 12,15, 18, 20 ve 22. Maddeleri ters olarak kodlanmaktadır. Kültürel duyarlılık ölçeği, (1) kesinlikle katılmıyorum, (2) katılmıyorum ,(3)kararsızım, (4)katılıyorum ve (5)kesinlikle katılıyorum şeklinde 5'li likert tipi bir yapıya sahiptir.

\section{BULGULAR}

\subsection{Demografik Değişkenler}

Bu bölümde, araştırma kapsamında ankete katılanlara ilişkin temel bilgiler verilmiştir. Tablo 1 katılımcıların; medeni durumlarına, cinsiyetlerine, yer aldıkları yas aralığına, aldıkları eğitim düzeylerine, işletmedeki pozisyonlarına ve iş tecrübe durumlarına ilişkin temel tanımlayıcı bilgileri içermektedir.

Tablo 1: Katılımcıların Kişisel Bilgileri

\begin{tabular}{|c|c|c|c|c|c|}
\hline Medeni Durum & (n) & $(\%)$ & Eğitim & (n) & $(\%)$ \\
\hline Bekar & 262 & 50,7 & İlköğretim & 14 & 2,7 \\
\hline Evli & 255 & 49,3 & Ortaöğretim & 316 & 61.1 \\
\hline Toplam & 517 & 100 & Üniversite & 175 & 33,8 \\
\hline Cinsivet & $(n)$ & (\%) & Lisansüstü & 12 & 2,3 \\
\hline Kadın & 204 & 39.5 & Toplam & 517 & 100 \\
\hline Erkek & 313 & 60,5 & Yas & $(n)$ & $(\%)$ \\
\hline Toplam & 517 & 100 & 20/25 Arası & 162 & 31,3 \\
\hline Calıstığı Konum & $(n)$ & (\%) & 26/30 Arası & 131 & 25,3 \\
\hline Servis Elemanı & 94 & 18,2 & 31/35 Arası & 84 & 16,2 \\
\hline Anketör & 19 & 3,7 & 36/40 Arası & 60 & 11,6 \\
\hline Önbüro Calıșanı & 59 & 11,4 & 41/45 Arası & 45 & 8,7 \\
\hline Satıs danısmanı & 43 & 8,3 & 46 ve Üzeri & 35 & 6,8 \\
\hline Güvenlik & 32 & 6,2 & Total & 517 & 100,0 \\
\hline Mutfak Calısanı & 60 & 11.6 & İs Tecrübesi & (n) & (\%) \\
\hline Sağlık Calıșanı & 6 & 1,2 & $1 / 5 Y_{l} I$ & 340 & 65,8 \\
\hline Halkla İliskiler & 28 & 5,4 & $6 / 10 Y_{1} 1$ & 128 & 24.8 \\
\hline Yönetici & 49 & 9,5 & $11 / 15 Y_{l} l$ & 33 & 6,4 \\
\hline Kat Hizmetleri çalıșanı & 107 & 20,7 & $16 / 20 Y_{1} l$ & 11 & 2,1 \\
\hline Müsteri temsilcisi & 20 & 3,9 & 21 Yıl ve Üzeri & 5 & 1,0 \\
\hline Toplam & 517 & 100,0 & Total & 517 & 100,0 \\
\hline
\end{tabular}

Tablo 1'de çalışmaya katılan katılımcıların kişisel bilgileri yer almaktadır. Katılımcıların medeni durumlarına göre \%50,7'si bekar, \%49,3'ünün evli olduğu belirlenmiştir. Eğitim durumları dikkate alındığında \%2,7'sinin ilköğretim mezunu, \%61,1'inin ortaöğretim mezunu, \%33,8'inin üniversite mezunu ve \%2,3'ünün lisansüstü eğitime sahip oldukları görülmektedir. Katılımcıların \%31,3’ü 20-25 yaş aralığında, \%25,3'ü 26-30 yaş aralığında, 
\%16,2'si 31-35 yaş aralığında, \%11,6'sı 36-40 yaş aralığında, \%8,7'si 41-45 yaş aralığında ve son olarak \% 7,1'i 46 yaş ve daha üstü yaş aralığındadır. Katılımcıların cinsiyet durumlarına göre katılımcıların \%39'5'i kadın ve \%60,5'i de erkek katılımcılardan oluşmaktadır. Katılımcıların işletmelerde çalıştığı pozisyonlar incelendiğinde, \% 20,7 'sinin kat hizmetleri çalışanları, \%11,6'sının mutfak çalışanı, \%18'2sinin servis elemanı, \%11'4'ünün önbüro görevlisi olduğu belirlenmiştir. Demografik özelliklerden sonuncusu katılımcıların iş tecrübesi ile ilgilidir. Çalışanların \%65,8'inin 5 yıl ve altında tecrübeye sahip olduğu, \%24,8'inin 6-10 yıl arası ve \%6,4'ünün 11-15 yıl aralığında iş deneyimine sahip olduğu belirlenmiştir.

\subsection{Faktör Analizi Sonuçları}

Araştırmanın bu bölümünde, çalışanların kültürlerarası duyarlılık düzeylerini belirlemeye yönelik hazırlanan ölçeğin yapı geçerliliğinin sınanabilmesi için açıklayıcı faktör analizi (AFA) uygulanmıştır. Çalışmada ele alınan örneklemin sayısı (517 adet) dikkate alındığında, 0,05 anlamlılık düzeyinde bir sonuca ulaşmak için, faktör ağırlığı veya faktör yükü (factor loadings) katsayılarının 0,4'ten küçük olmaması gerekmektedir. Bu nedenle, mutlak değeri 0,4'ten küçük olan faktör yüklerine analiz sonuç tablolarında yer verilmemiştir. Verilerin faktör analizine uygunluğu Kaiser-Meyer-Olkin (KMO) katsayısı ve Barlett Sphericity testi ile incelenmiştir. KMO değeri $0,78^{\prime}$ dir. Barlett Sphericity testi sonuçları da anlamlıdır ( $\left.x 2=1415,48 ; p<0,000\right)$. KMO (Kaiser-Meyer-Olkin) testi, örnekleme yeterliliğini ölçmeye yarayan bir test olup örnek büyüklüğü ile ilgilenir. Bu testin sonucu bir oran olup \% 60,0'ın üstünde olması arzulanır (Yavuz, 2007: 96). Araştırmamızda ise bu oran \% 78 olarak belirlenmiş ve istenilen düzeyde olduğu görülmüştür. Her iki test sonucuna bakıldığında, ölçeğe faktör analizi yapılmasının uygun olacağı görülmüştür. Analiz esnasında ortak varyans (Communality) değerlerine de bakılmıştır. Ortak varyans bir değişkenin analizde yer alan diğer değişkenlerle paylaştığı varyans miktarıdır. Analiz sırasında faktör yük değeri 0,40 ya da daha yüksek olanlar analize alınmış, faktör yük değeri 0,40'in altında bulunan maddeler analizden çıkartılmıştır. Ayrıca, birden fazla faktörde, 0.10'dan daha az bir farkla yer alan her hangi bir madde, binişik bir madde olarak değerlendirildiğinden, bu özellikteki maddeler de ölçekten çıkartılmıştır (Karagöz ve Kösterelioğlu, 2008). Ortak varyans değerlerine ve diğer analizlere bakılarak 24 ifadeden oluşan kültürlerarası duyarlılık ölçeği 16 ifadeye düşürülmüştür. Çalışanların kültürlerarası duyarlılık düzeylerini belirlemek amacıyla oluşturulan değişkenlerin güvenilirlik katsayısı (Cronbach's Alfa) 0.84 olarak bulunmuştur. Araştırmada yer alan değişkenlerin yüksek güvenilirliğe sahip olduğu görülmektedir. Analiz sonucunda belirlenen her bir faktörün güvenilirliklerine de bakılmıştır. Tablo 2'deki sonuçlara göre tüm faktörlerin güvenilirlik katsayısının yeterli olduğu görülmüştür.

Tablo 2: Kültürlerarası Duyarlılık Ölçeğine illişkin Faktör Analizi Sonuçları

\begin{tabular}{|c|c|c|c|c|c|}
\hline & 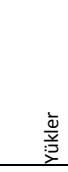 & 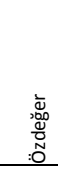 & 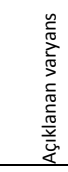 & $\begin{array}{l}\frac{\pi}{0} \\
\frac{0}{4} \\
\end{array}$ & $\begin{array}{l}\text { ப் } \\
\text { 荌 }\end{array}$ \\
\hline İletişimde kendine güvenme & & 3,10 & 16,81 & ,86 & 3,44 \\
\hline Diğer kültürlerden olan insanların dar görüslü olduğunu düsünürüm & 745 & & & & \\
\hline Farklı kültürlerden olan insanlarla iletişim kurarken kendimden oldukça eminimdir. & ,684 & & & & \\
\hline Farklı kültürlerden olan insanların karşısında konuşmakta çok zorlanııım. & ,675 & & & & \\
\hline Farklı kültürlerden olan insanlarla iletişim kurarken genellikle kendimi yararsız hissederim. & ,637 & & & & \\
\hline Farklı kültürlerden olan insanlarla birlikte olmaktan hoşlanmam. & ,603 & & & & \\
\hline Farklı kültürlerden olan insanlarla birlikteyken genellikle cesaretim kırılır. &, 575 & & & & \\
\hline İletişimde dikkatli olma & & 2,54 & 11,25 &, 83 & 3,84 \\
\hline Farklı kültürlerden olan insanlarla iletişim kurarken olabildiğince çok bilgi edinmeye çalışırım. & 693 & & & & \\
\hline
\end{tabular}




\begin{tabular}{|c|c|c|c|c|c|c|}
\hline \multicolumn{2}{|c|}{ Farklı kültürlerden olan insanlarla iletişim kurarken nezaket kurallarına daha dikkat ederim. } & 610, & & & & \\
\hline \multicolumn{2}{|c|}{ Farklı kültürdeki akranlarım hakkında bir kanıya varmadan önce beklemeyi tercih ederim. } & 602, & & & & \\
\hline \multicolumn{2}{|c|}{ İletişimimiz boyunca kültürel olarak farklı olan bireylere genellikle olumlu yaklaşııım. } &, 595 & & & & \\
\hline \multicolumn{2}{|l|}{ iletişimde sorumluluk } & & 1,19 & 10,18 & 80 & 3,64 \\
\hline \multicolumn{2}{|c|}{ İletişimimiz boyunca kültürel olarak farklı olan bireylerin imalı yorumlarına karşı hassasımdır. } & ,793 & & & & \\
\hline \multicolumn{2}{|c|}{ Kendi kültürümün diğer kültürlerden daha iyi olduğunu düşünürüm. } & ,711 & & & & \\
\hline \multicolumn{2}{|l|}{ Iletişimden hoşlanma } & & 1,15 & 9,17 & 81 & 3,69 \\
\hline \multicolumn{2}{|c|}{ Farklı kültürlerden olan insanlarla iletişimde bulunmaktan hoşlanırım. } & ,740 & & & & \\
\hline \multicolumn{2}{|c|}{ Farklı kültürlerden olan insanlarla iletişim kurarken kendimden oldukça eminimdir. } & ,723 & & & & \\
\hline \multicolumn{2}{|l|}{ Kültürel farklıııklara saygı } & & 1,01 & 8,97 & ,72 & 3,83 \\
\hline \multicolumn{2}{|c|}{ Farklı kültürlerden olan insanlara karşı açık fikirliyimdir. } & ,753 & & & & \\
\hline \multicolumn{2}{|c|}{ Farklı kültürlerden olan insanlarla iletişim kurarken kendime güvenirim. } &, 551 & & & & \\
\hline Cronbach Alfa & 0,84 & & & & & \\
\hline Açılanan toplam varyans & 56,33 & Kikare: & & & & \\
\hline KMO örneklem yeterliliği ölçümü & 0,78 & P:, 000 & & & & \\
\hline
\end{tabular}

Faktör analizi sonucunda özdeğeri birden büyük beş boyut belirlenmiştir. Belirlenen bu beş boyut toplam varyansın \%56,33'ünü açıklamaktadır. Birinci boyut iletişimde kendine güvenme, ikinci boyut iletişimde dikkatli olma, üçüncü boyut illetişimde sorumluluk, dördüncü boyut İletişimden hoşlanma ve beşinci boyut Kültürel farklılıklara saygı olarak isimlendirilmiştir.

\subsection{Hipotezlerin Testi}

Araştırmanın bu bölümüne kadar Edremit Körfezinde turizm işletmelerinde çalışan kişilerin kültürlerarası duyarlılık düzeyleri ile ilgili ölçek geliştirme çalışmaları yapılmıştır. Bu bölümde ise, araştırmanın bir diğer amacına yönelik olarak çalışanların demografik özellikleri ile kültürlerarası duyarlılık düzeyleri arasında istatistiksel olarak anlamlı farklılıklar olup olmadığı ile ilgili bilgiler farklılık analizi (" $t$ " testi ve ANOVA) ile belirlenmeye çalışılmıştır.

Tablo 3: Demografik Özelliklere Göre "t Testi” ve ANOVA Sonuçları

\begin{tabular}{|c|c|c|c|c|c|c|c|}
\hline \multirow[t]{2}{*}{ Faktörler } & \multicolumn{3}{|c|}{ "t" Testi } & \multicolumn{4}{|c|}{ Anova (F) } \\
\hline & 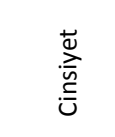 & 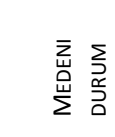 & 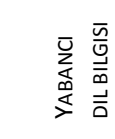 & m & $\sum_{\substack{E \\
\text { 焉 }}}$ & 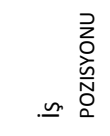 & 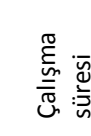 \\
\hline İletişimde Kendine Güvenme & 858 & ,433 & ,273 & $3,453 * *$ & $2,506 * *$ & $2,204 * *$ & 1,158 \\
\hline İletişimde Dikkatli Olma & ,036 & 1,137 &,- 270 & 645 & $3,821 * *$ & ,554 & ,702 \\
\hline İletişimde Sorumluluk & ,216 & $-1,758$ & ,823 & 985 & $2,396 * *$ & ,885 & ,789 \\
\hline İletişimden Hoşlanma & ,196 & $-1,698$ & 1,016 & 152 & 691 &, 560 &, 438 \\
\hline Kültürel Farklılıklara Saygı & $5,533 * *$ & $-2,506 * *$ & $2,212 * *$ & 1,475 & $2,702 * *$ & 1,397 &, 523 \\
\hline
\end{tabular}




\section{Ölçek Değerleri: 1=Kesinlikle katılmıyorum - 5=Kesinlikle katılıyorum, Anlamlıık Düzeyi: **p<.05}

Ileri sürülen hipotezlere ait " $\mathrm{t}$ testi" ve Anova ile ortaya çıkan sonuçlar Tablo 3'te gösterilmektedir. Buna göre, araştırmada öne sürülen 7 adet hipotezden 6 tanesi $(\mathrm{H} 1, \mathrm{H} 2, \mathrm{H3}, \mathrm{H} 4, \mathrm{H} 5, \mathrm{H} 6)$ çalışma sonuçlarına göre desteklenmiştir. 1 hipotez ise (H7) çalışma sonuçlarına göre desteklenmemiştir.

Araştırmanın 1. hipotezinde yöneticilerin cinsiyetlerine göre kültürlerarası duyarlılık algılarında farklıık olup olmadığı " $\mathrm{t}$ " testi ile analiz edilmiştir. Elde edilen verilere göre bağımsız değişken olarak cinsiyetin sadece "Kültürel farklııklara saygı" boyutunda anlamlı bir farklılık oluşturduğu görülmektedir. Levene's testi sonucuna göre varyansların eşit olduğu görülmektedir. Bu nedenle varyansların eşit olduğu satırdaki " $t$ " değeri Tablo 3'te gösterilmiştir. Elde edilen verilere göre, "Kültürel farklııklara saygı" olarak adlandırılan Faktör 5'e kadınların erkeklere göre daha fazla önem verdikleri ve bu nedenle anlamlı bir farklılık olduğu $(t=5,53, p<.05)$ görülmektedir. Kültürlerarası duyarlılık ölçeğinin diğer dört boyutunda cinsiyete göre anlamlı bir farkılık bulunmamıştır. Sonuçta cinsiyete göre "Kültürel farklııılara saygı" ile ilgili farklılık oluştuğu için H1 hipotezi kabul edilmiştir. Medeni durumlarına göre yapılan farklılık analizinde, cinsiyet değişkeninde olduğu gibi, "Kültürel farklılıklara saygı" boyutunda farklıık tespit edilmiştir. Evli olanların bekarlara göre Kültürel farklılıklara saygı düzeylerinin yüksek olduğu görülmektedir. Bu nedenle medeni duruma göre "Kültürel farklııklara saygı" ile ilgili farklıık oluştuğu için $\mathrm{H} 2$ hipotezi kabul edilmiştir. Katılımcıların yabancı dil bilgisine yönelik yapılan farklıık analizinde diğer iki hipotezde olduğu gibi "Kültürel farklııklara saygı" boyutunda farkılık tespit edilmiştir. Araştırma hipotezlerinin test edilmesinde kullanılan ikinci test yöntemi anava analizidir. Anova testi ile gerçekleştirilen farklıık analizinde, katılımcıların yaş, eğitim seviyeleri ve işyerinde çalıştıkları pozisyona göre kültürlerarası duyarlıık düzeylerinde farklııklar tespit edilmiş ve $\mathrm{H} 4, \mathrm{H} 5$ ve $\mathrm{H} 6$ kabul edilmiştir. Gerçekleştirilen analiz sonucunda sadece çalışanların çalışma sürelerine göre kültürlerarası duyarlılık düzeyleri arasında anlamlı farklılık tespit edilmemiş ve bunun neticesinde $\mathrm{H} 7$ kabul edilmemiştir.

\section{SONUÇ VE ÖNERILER}

Çok kültürlü ortamların etkin bir biçimde yönetimi, konaklama işletmeleri gibi hizmet karşılaşmalarının sık yaşandığı ortamlarda kritik derecede önem taşımaktadır. Son yıllarda turizm hareketlerinin çok fazla sayıda artmasıyla birlikte konaklama işletmelerinde, hizmeti sunan ve hizmeti alan farklı kültürden olabildiği gibi hizmet sunucunun çalışma arkadaşları ve üstleri, hatta otel yönetimi farklı kültürlerden olabilmektedir. Konaklama işletmelerinin karşılaşacakları zorluklardan en önemlisi kültür farklııklarının işletmecilikle ilgili bir çok konuyu doğrudan etkilemesidir. (Temizel vd., 2008). Bu doğrultuda bu araştırmada, turizm işletmelerinde çalışan personelin kültürel duyarılık düzeylerinin belirlenmesi ve çalışanların demografik özelliklerine göre kültürel duyarııık düzeyleri arasında anlamlı fark olup olmadığının tespiti amaçlanmıştır.

Çalışmanın ilk bölümünde Chen ve Starosta'nın (2000) geliştirmiş olduğu kültürlerarası duyarlılık ölçeği açıklayııı analizine tabi tutulmuştur. Gerçekleştirilen açıklayıcı faktör analizi sonuçlarına göre 5 boyutta toplam 16 sorudan oluşan ölçek ortaya çıkmıştır. Sonuçta bu örneklem grubu üzerinde 24 sorulu ölçeğin değil de 16 sorulu bir ölçeğin çalışmada kullanılan örneklem grubu için daha anlamlı sonuçlar verdiği görülmüştür. Çalışmanın ikinci bölümünde çalışmada yer alan hipotezler test edilmiştir. Teste tabi tutulan 7 adet hipotezden 6 tanesi $(\mathrm{H} 1, \mathrm{H} 2, \mathrm{H3}, \mathrm{H4}, \mathrm{H5}, \mathrm{H6})$ desteklenirken, 1 tanesi $(\mathrm{H} 7)$ çalışma sonuçlarınca desteklenmemiştir.

Araştırmanın ilk hipotezinde yöneticilerin cinsiyetlerine göre kültürlerarası duyarlıık algılarında farklılık olup olmadığı analiz edilmiş, elde edilen verilere göre bağımsız değişken olarak cinsiyetin sadece "Kültürel farklııklara saygı" boyutunda anlamlı bir farklılık oluşturduğu ve kadınların erkeklere göre kültürel farklııklara daha fazla saygı duydukları belirlenmiştir. Medeni durumlarına göre yapılan farkılık analizinde, cinsiyet değişkeninde olduğu gibi, "Kültürel farklııılara saygı" boyutunda farklılık tespit edilmiş, evli olanların bekarlara göre kültürel farklılıklara daha fazla saygı gösterdikleri tespit edilmiştir. Katılımcıların yabancı dil bilgisine yönelik yapılan farklılık analizinde, cinsiyet ve medeni durum değişkenlerinde olduğu gibi, yabancı dil bilen personelin bilmeyenlere göre kültürel farklııklara daha fazla saygı duydukları belirlenmiştir. Anova testi ile gerçekleştirilen farklıık analizinde, katııımcıların yaş, eğitim seviyeleri ve işyerinde çalıştıkları pozisyona göre kültürlerarası duyarlılık düzeylerinde farklııılar tespit edilmiş ve $\mathrm{H} 4, \mathrm{H} 5$ ve $\mathrm{H} 6$ kabul edilmiştir. Katılımcıların yaş aralıklarına göre "illetişimde kendine güvenme" boyutunda farklılık tespit edilmiştir. Bu farklıı̆ı̆n hangi yaş grupları arasında olduğunun belirlenmesi için gerçekleştirilen tukey testi sonuçlarına göre 20-30 yaş aralığı ile 
36 yaş ve üstündeki katılımcıların anlamlı farklılığa sahip olduğunu söylemek mümkündür. Katılımcıların eğitim durumlarına göre gerçekleştirilen farklılık analizinde "iletişimden hoşlanma" boyutu haricinde diğer dört boyutta anlamlı farklılıklar tespit edilmiştir. Özellikle ilköğretim ile lisans ve lisansüstü eğitim görmüş çalışanlar arasında anlamlı farkılıklar bulunmaktadır. Çalışanların işyerinde çalıştıkları pozisyonlara göre gerçekleştirilen farklıık analizinde "iletişimde kendine güvenme" boyutunda önbüro, halkla ilişkiler çalışanları ile mutfak ve kat hizmetleri çalışanları arasında anlamlı farklılıklar tespit edilmiştir. Son olarak gerçekleştirilen analiz sonucunda sadece çalışanların çalışma sürelerine göre kültürlerarası duyarlıık düzeyleri arasında anlamlı farklılık tespit edilmemiştir.

Çalışmada ortaya çıkan demografik değişkenlere göre kültürlerarası duyarlılık ile ilgili anlamlı farklılıklar, demografik özelliklerin algı ve davranışları etkilediğini ortaya koyan önceki çalışmaları (Arıcı, 2002; Güven, Bakan ve Yeşil, 2005; Özkaya, Kocakoç ve Kara, 2006; Gürbüz, 2007) desteklemektedir. Ayrıca Çakır 'ın (2010) kültürler arasındaki iletişim sürecinde sağlam eğitim ve kültür altyapısına sahip olmayan bireylerin davranışlarında bazı sapmaların ortaya çıkabileceği iddiası bu çalışma sonuçlarıyla özellikle eğitim düzeylerine göre dört farklı boyutta görülen farklılıklar neticesinde desteklenmiştir.

Farklı kültürlerden birçok insanın bir arada olduğu turizm işletmelerinde çalışanların demografik özellikleri kültürel duyarlııklarını etkilemektedir. Özellikle çalışanların eğitim düzeyleri ile kültürel duyarlııkları arasında önemli bir ilişki bulunmaktadır. Çalışma sonuçlarında görülen en önemli nokta, çalışanların eğitim düzeyleri yükseldikçe kültürlerarası duyarlıık düzeyleri artmaktadır. Turizm işletmelerinin eğitimli personel çalıştırmaları çalışanların müşteri ile olan iletişimini güçlendirecektir. Eğitimli personel istihdam etmenin her alanda işletmelere olan bilinen katkıları, çalışanların kültürlerarası duyarlıı̆̆ı açısından da bu çalışma sonuçlarıyla desteklenmiştir.

Araştırma zaman kısıtılığı ve verilerin toplanması aşamasında karşılaşılan bazı güçükler nedeniyle çok geniş bir örneklem üzerinde yapılamamıştır. Bu da çalışmanın genelleştirilmesini etkilemektedir. Bundan sonra yapılacak olan çalışmalarda daha geniş bir örnek kitleye ulaşılması genelleştirmeyi sağlayacaktır. Ayrıca farkı turizm destinasyonlarda ölçek uygulanıp geliştirilebilir ve bu çalışma verileri ile kıyaslamalar yapılabilir.

\section{KAYNAKÇA}

Aksoy, Z., (2012) “Uluslararası Göç ve Kültürlerarası İletişim” Uluslararası Sosyal Araştırmalar Dergisi, Cilt: 5, Sayı: 20, Volume: 5, Issue: 20, ss. 292-303.

Arıcı, A.E.Durmuş (2002). "Yönetici Yaşının Liderlik Davranışları Üzerindeki Etkileri: Bankacılık Sektöründen Bir Grup Yönetici Üzerinde Bir Araştırma" Akdeniz i.i. B.F. Dergisi, 3, 1-20.

Belber, B. (2009) "Tatil Turizminde Turistlerin Konaklama İşletmesi Tercihinde Kültürün Etkisi”, Erciyes Üniversitesi İktisadi ve İdari Bilimler Fakültesi Dergisi, 34, ss.91-116.

Bekiroğlu, O., Balcı, Ş., (2014) “Kültürlerarası Illetişim Duyarlılığının İzlerini Aramak: “iletişim Fakültesi Öğrencileri Örneğinde Bir Araştırma” Türkiyat Araştırmaları Dergisi, ss.429-460.

Bennett, M., J, (1986) "A Developmental Approach to Training for Intercultural Sensitiviy", International Journal of Intecultural Relations, $10(2), 179-195$.

Bulduk, S., Tosun, H. ve Ardıç, E. (2011) Türkçe Kültürler Arası DuyarlılıkÖlçeğinin Hemşirelik Öğrencilerinde Ölçümsel Özellikleri. Türkiye Klinikleri J. Med. Ethics, 19 (1): 25-31.

Chen, G., (1997) "A Review of the Concept of Intercultural Sensitivity", Paper Presented at the Biennial Convention Of Pacific and Asian Communication Association, January, Honolulu, Hawaii.

Chen, G., Starosta, W., (2000) "The Development and Validation of the Intercultural Sensitivity Scale" Paper presented at the Annual Meeting of the National Communication Association, Seattle, WA, November 8- 12.

Çakir, M. (2010). Kültürlerarası Illetişimin Bir Yönü: Özün Ötekileştirilerek Yabancılaştırılması. Anatolia: Turizm Araştırmaları Dergisi, 21(1), 75-84.

Dökmen, Ü., (2002) “ Illetişim Çatışmaları ve Empati” (20. Basım). İstanbul: Sistem

Egan, G., (1994) “Psikolojik Danışmaya Giriş”, Akkoyun F. (Çev). Ankara: Form Ofset. 
Gürbüz, A. (2007)." Eğitim Seviyesinin İşö Tatmini Üzerindeki Etkisinin Turizm Sektörü Açısından Değerlendirilmesi," Doğuş Üniversitesi Dergisi, 8(1), 36-46.

Güven, M., Bakan, i. ve Yeşil S. (2005). "Çalışanların Iş ve Ücret Tatmini Boyutlarıyla Demografik Özellikler Arasındaki ilişkiler, "Yönetim ve Ekonomi Dergisi, 12(1), 127-151.

Hall, E., T., Hall, M., R., (1990) “Understanding Cultural Differences”, USA: Intercultural Press, Inc.

Hammer, M., R., Bennett, M.,.., Wiseman, R., (2003) "Measuring Intercultural Sensitivity: The Intercultural Development Inventory", International Journal of Intercultural Relations, 27 (4),421-443.

Kartarı, A., (2001) “Farklılıklarla Yaşamak: Kültürlerarası iletişim”, Ankara: Ürün Yayınları.

Korkut, F., (2005) "Yetişkinlere Yönelik iletişim Becerileri Eğitimi” Hacettepe Üniversitesi Eğitim Fakültesi Dergisi , 143-149.

Özer, K. (2006) “iletişimsizlik Becerisi”, Altıncı basım, Sistem yayıncılık: İstanbul.

Özkaya, M., Kocakoç, İ. ve Kara E. (2006). Yöneticilerin Örgütsel Bağlıııları ve Demografik Özellikleri Arasındaki Illişkileri İncelemeye Yönelik Bir Alan Çalışması, 13(2), 77-96.

Selçuk, A., (2005) “Kültürlerarası Iletişim Açısından Gündelik iletişim Davranışları”, Selçuk Üniversitesi Sosyal Bilimler Enstitüsü Dergisi, 13, $1-17$.

Temizel, H., Turan, E., Temizel, M., (2008) "Küresel İşletmecilikte Ülkelerin Sosyo- Kültürel Yapılarından Kaynaklanan Sorunlar", Konya Selçuk Üniversitesi, Sosyal Bilimler Enstitüsü Dergisi, 459-465.

Yavuz, M. C. (2007). Uluslararası Destinasyon Markası Oluşturulmasında Kimlik Geliştirme Süreci: Adana Örneği, Çukurova Üniversitesi Sosyal Bilimler Enstitüsü. (Yayınlanmamış Doktora Tezi).

Yılmaz, H., (2004) “Öğretmenim Lütfen Bu Kitabı Okur Musun?” Yirmi yedinci baskı. Çizgi kitapevi: Konya.

internet Kaynakları:

http://www.ayvalikda.com/ayvalik-otelleri.html

www.balikesir-edremit.gov.tr

$\underline{\text { www.burhaniye.bel.tr }}$

www.tursab.gov.tr 